Article

\title{
Investigation of Plasmid DNA Delivery and Cell Viability Dynamics for Optimal Cell Electrotransfection In Vitro
}

\author{
Sonam Chopra ${ }^{\circledR}$, Paulius Ruzgys ${ }^{\circledR}$, Martynas Maciulevičius, Milda Jakutavičiūtè \\ and Saulius Šatkauskas *(D) \\ Biophysical Research Group, Faculty of Natural Sciences, Vytautas Magnus University, Vileikos Str. 8, \\ LT 44404 Kaunas, Lithuania; sonam.chopra@vdu.lt (S.C.); paulius.ruzgys@vdu.lt (P.R.); \\ martynas.maciulevicius@vdu.lt (M.M.); milda.jakutaviciute@vdu.lt (M.J.) \\ * Correspondence: saulius.satkauskas@vdu.lt; Tel.: +370-37-32-79-20
}

Received: 17 August 2020; Accepted: 28 August 2020; Published: 2 September 2020

\begin{abstract}
Electroporation is an effective method for delivering plasmid DNA molecules into cells. The efficiency of gene electrotransfer depends on several factors. To achieve high transfection efficiency while maintaining cell viability is a tedious task in electroporation. Here, we present a combined study in which the dynamics of both evaluation types of transfection efficiency and the cell viability were evaluated in dependence of plasmid concentration as well as at the different number of high voltage (HV) electric pulses. The results of this study reveal a quantitative sigmoidal $\left(R^{2}>0.95\right)$ dependence of the transfection efficiency and cell viability on the distance between the cell membrane and the nearest plasmid. We propose this distance value as a new, more accurate output parameter that could be used in further optimization studies as a predictor and a measure of electrotransfection efficiency.
\end{abstract}

Keywords: plasmid; DNA; electroporation; electrotransfection; cell viability

\section{Introduction}

The importance of gene therapy in various biomedical applications has been on an increase in the recent years. Over the last few decades, viral vectors have been widely used for the effective gene transfer to the target cells or tissues [1]. However, viral vectors pose serious safety concerns due to their immunogenicity, oncogenicity and/or inflammatory potential [2]. Hence, a non-viral gene delivery method is a promising alternative that bypasses the inherent problems of the viral gene vectors [3]. Electroporation is one of the techniques that is widely exploited as a non-viral gene delivery method. It relies on electric field induced transient alteration of cell membrane permeability to introduce various molecules, including plasmid DNA, to the interior of the cell [4].

To trigger electroporation, the cell must be treated with electric field of over-threshold intensity [5], which, in turn, induces a change in the transmembrane potential of the cell [6]. According to the hydrophilic pore theory, once the electric field induced transmembrane potential exceeds the threshold value, which is reported to be in the range between $0.25-1.0 \mathrm{~V}$, hydrophilic pores occur in the cell plasma membrane [7-9]. The side of the cell facing the positive electrode is permeabilized first due to the negative interior of the cell, and later, another side of the cell facing the negative electrode gets permeabilized. [10]. Depending on the electric field parameters, electroporation of the cell membrane can be reversible or irreversible [11]. As suggested by the name, irreversible electroporation is permanent and can be utilized for non-thermal ablation of malignant cells [12]. On the contrary, reversible electroporation is transient and, if the electric field parameters are properly 
chosen, membranes reseal and cells remain viable [11]. One of the applications for reversible electroporation is the transfer of hydrophilic or amphiphilic molecules from extracellular matrix into the cell through the electropores [3], which are estimated to have radii of 1-60 $\mathrm{nm}$ [13]. Therefore, it is believed that the mechanism of action that drives small molecules (less than electropore size) into the cells during the process of electrotransfer is mainly gradient diffusion. However, it is observed that molecules exceeding the size of the electropores also enter the cell after electroporation, yet different pathways are being utilized [14]. Plasmid DNA, considered as a large molecule, is dragged towards the cell via electrophoresis during the electric pulses, forms a complex with electroporated part of the membrane [15] and later is translocated through the plasma membrane by various types of endocytosis [16,17]. However, to achieve protein expression, the translocation of the plasmid DNA is not enough since the plasmid must migrates to the nucleus where it undergoes transcription, after which mRNA translation can begin [9].

Although the feasibility of electrotransfection has been shown numerous times [17-19], the widespread implementation of this method in clinical and industrial applications is still, at least partially, limited as a result of poor transfection efficiency [20]. Numerous studies have been performed on the optimization of the electric field [21-23] and electroporation medium parameters [24,25] to achieve efficient electrotransfection. However, the consistent and detailed research is neecessary to be performed regarding other electroporation parameters, such as plasmid concentration. A few research works show an improvement in the electrotransfection efficiency with an increase in plasmid concentration. However, they do not report cell viability data $[18,19,26]$. Others reported an increase in cell electrotransfection efficiency with higher plasmid concentration and noted the decrease in cell viability to $\sim 70-80 \%$. However, these works did not provide thorough research on the dependence of cell viability in the wide range of plasmid DNA concentration [27-29]. Therefore, the explicit dependencies of transfection efficiency and cell viability on plasmid concentration remain unclear. To address this, we present an investigation where both transfection efficiency and cell viability dynamics in dependence on plasmid concentration are evaluated in a single study at the same experimental conditions using different number of high voltage (HV) pulses. Additionally, we have evaluated the distance between cell plasma membrane and the nearest plasmid DNA, which seems to be important for the DNA electrotransfer to the cell as the diffusion of plasmid DNA is limited due to its large size [30]. For the first time, we show a quantitative, correlation-based dependency on the distance between the cell and plasmid DNA molecule with cell transfection efficiency and with cell viability. We propose the distance between the plasmid and the cell as the new value for the optimization of molecular delivery.

\section{Materials and Methods}

Cell culture: Chinese Hamster Ovary (CHO-K1) cells were grown as a monolayer at $37^{\circ} \mathrm{C}$ in a $5 \%$ $\mathrm{CO}_{2}$ humidified incubator and maintained in Dulbecco's modified Eagle's medium supplemented with $1 \%$ L-glutamine, 10\% fetal bovine serum (Sigma, St Louis, MO, USA) and 1\% penicillin-streptomycin solution (100 U/mL penicillin and $100 \mu \mathrm{g} / \mathrm{mL}$ streptomycin). Trypan Blue Stain exclusion test (Invitrogen, Carlsbad, CA, USA) was used to measure the cell viability during passaging. Cells were passaged $24 \mathrm{~h}$ before the experiments and every 2-3 days for routine passaging.

Plasmid DNA: The pMAX-GFP plasmid DNA (Amaxa, Cologne, Germany) (3485 bp) was propagated in E. coli DH5 $\alpha$ and purified using the EndoFree Plasmid GigaPrep kit (Qiagen, Chatsworth, CA, USA) according to the manufacturer's instructions. The extracted plasmid DNA was validated by electrophoresis on agarose gel. The concentration was determined by measuring the absorbance at $260 \mathrm{~nm}$ in a spectrophotometer (Nanodrop 2000, Thermo Fisher, Washington, DC, USA).

Electroporation medium and electroporator: Electroporation medium was composed of sucrose (242 mM), $\mathrm{Na}_{2} \mathrm{HPO}_{4}(5.5 \mathrm{mM}), \mathrm{NaH}_{2} \mathrm{PO}_{4}(3 \mathrm{mM})$ and $\mathrm{MgCl}_{2}(1.7 \mathrm{mM})$. Electroporation medium was isosmotic $(270 \mathrm{mOsm})$ and had $7.1 \mathrm{pH}$. The measured specific conductivity of electroporation medium was $0.1 \mathrm{~S} / \mathrm{m}$ at $25^{\circ} \mathrm{C}$. 
During electroporation, 1, 2, or 3 square-wave high voltage $(\mathrm{HV})$ pulses $(1400 \mathrm{~V} / \mathrm{cm}$ pulse strength, $100 \mu$ s pulse duration, $1 \mathrm{~Hz}$ repetition frequency) were delivered using electroporator (BTX T820, Harvard Apparatus, Holliston, MA, USA). Experiments were performed with stainless steel plate electrodes produced in Biophysical research laboratory, Vytautas Magnus University. The fixed distance of $2 \mathrm{~mm}$ between the electrodes was used for all experiments.

DNA electrotransfer and result measurement procedure: During the experiment, cells were trypsinized, centrifuged ( $2 \mathrm{~min}$ at $170 \mathrm{RCF}$ ) and suspended in low conductivity electroporation medium at a concentration of 2 million cells per milliliter. For each experimental point, $45 \mu \mathrm{L}$ of cell suspension containing $9 \times 10^{4}$ cells were used, and $5 \mu \mathrm{L}$ of plasmid solution was added to the sample to get final plasmid concentration of $10-600 \mu \mathrm{g} / \mathrm{mL}$. The resulting solution $(50 \mu \mathrm{L})$ was electroporated and removed by the gentle tap of the electrodes at the bottom of 24 well plate. Then the cells were incubated for $10 \mathrm{~min}$ to reseal the electroporated cell membrane. Afterwards, the treated cells were supplemented with $950 \mu \mathrm{L}$ of growth medium. Then, $900 \mu \mathrm{L}$ of cell suspension was put into the incubator $\left(37^{\circ} \mathrm{C}, 5 \% \mathrm{CO}_{2}\right)$ for $24 \mathrm{~h}$ in 24 well tissue culture plate (TPP, Trasadingen, Switzerland). After $24 \mathrm{~h}$, cells we are trypsinized, centrifuged and resuspended in $100 \mu \mathrm{L}$ PBS for flow cytometry (BD Accuri C6, BD Biosciences, Franklin Lakes, NJ, USA) measurements. $1 \times 10^{4}$ cells were gathered from each experiment. For all measurements, flow rate was kept at $66 \mu \mathrm{L} / \mathrm{min}$ and the core size was $22 \mu \mathrm{m}$. The cells were excited using $488 \mathrm{~nm}$ (blue) laser, and the fluorescence was collected using 533/30 nm bandpass filter. The results were analyzed with BD Accuri C6 Software, obtaining the percentage of transfected cells (referred to as transfection efficiency (TE)) and mean cell fluorescence $(M C F)$ of transfected cell population. Total fluorescence (TF) was calculated using Equation (1):

$$
T F=\frac{T E * 10000 * M C F}{100}
$$

Cell viability was measured using the clonogenic assay. After the $10 \mathrm{~min}$ incubation and addition of $950 \mu \mathrm{L}$ of growth medium, $100 \mu \mathrm{L}$ of cell suspension was taken and put in $900 \mu \mathrm{L}$ of growth medium, and $44.4 \mu \mathrm{L}$ of this suspension ( 400 cells) was placed in $40 \mathrm{~mm}$ diameter Petri dish containing $2 \mathrm{~mL}$ of growth medium. The cells were grown in the incubator for 6 days, then the growth medium was removed, cell colonies were fixed with $70 \%$ ethanol for $10 \mathrm{~min}$ and stained using crystal violet solution. Afterwards, the cell colonies were scanned and counted using open-source imaging software ImageJ (National Institute of Health, Bethesda, MD, USA). The cell viability of control sample (cells not treated with electric pulses) was evaluated as $100 \%$, and the viability of the experimental samples were compared to that of the control.

Cell size measurements: Chinese hamster ovary $(\mathrm{CHO})$ cells were grown at $37^{\circ} \mathrm{C}$ in a $5 \% \mathrm{CO}_{2}$ humidified incubator for $24 \mathrm{~h}$ prior to the measurement. Afterwards, cells were trypsinized, centrifuged (300 RCF) and resuspended in PBS at concentration of $2 \times 10^{6}$ cells/mL and placed in Neubauer chamber. After 5 min incubation, cells were imaged using an inverted microscope (Nikon eclipse TS 100) with mounted camera (Moticam 2300/3.0M Pixel). Cell diameters were assessed by imageJ. At least 100 cells were counted to evaluate the cell size.

Calculation of the distance between electroporated cell membrane and the nearest plasmid: The distance between the cell membrane and the nearest plasmid was evaluated as follows. First, the volume of all cells in solution was calculated. For this, the average radius of a cell $(R)$ was estimated to be $9.47 \pm 0.09 \mu \mathrm{m}$ by imaging under inverted light microscope (Nikon eclipse TS 100) using Moticam 2300 camera and processing the images using open source software ImageJ (National Institute of Health, Bethesda, MD, USA). Then the volume of the cells in the sample was calculated by calculating the volume of a single spherical cell $\left(V_{\text {sphere }}\right)$ and multiplying it by the number of cells in sample $\left(N_{\text {cells }}\right)$ (Equation (2)):

$$
V_{\text {cells }}=V_{\text {sphere }} \times N_{\text {cells }}=4 \pi \frac{R^{3}}{3} \times 90000
$$


Then, the number of plasmids in the sample for each plasmid concentration was calculated using Equation (3):

$$
N_{\text {plasmids }}=c_{\text {molar }} \times N_{A} \times V_{\text {solution }}
$$

where $N_{\text {plasmids }}$ is the number of plasmids in the solution, $c_{\text {molar }}$ is the molar concentration of plasmid DNA (taking into the account that the molecular weight of pGFP plasmid is $\sim 2,154,743 \mathrm{~g} / \mathrm{mol}$ ), NA is the Avogadro's number (equal to $6.022 \times 1023)$, and $V_{\text {solution }}$ is the volume of the whole solution $(50 \mu \mathrm{L}$ in all of the experiments). Finally, assuming that the cells are evenly distributed in the solution and the plasmids are evenly distributed in the solution outside the cells, the distance $(D)$ between the plasmid and its nearest object (cell membrane or another plasmid) can be calculated by Equation (4):

$$
D=\sqrt[3]{\frac{V_{\text {solution }}-V_{\text {cells }}}{N_{\text {plasmids }}}}
$$

Statistical analysis: Each experimental point was repeated at least 6 separate times. The error bars in graphs are represented as standard error of mean \pm SEM. The statistical significance between samples was calculated using one-way ANOVA.

\section{Results}

\subsection{Transfection Efficiency and Cell Viability Dependence on Plasmid Concentration}

The CHO-K1 cells were used in order to systematically determine the effect of different plasmid concentrations on electrotransfection efficiency. GFP coding plasmid concentrations from 10 to $600 \mu \mathrm{g} / \mathrm{mL}$ were used and the evaluation of transfection efficiency was performed by flow cytometry $24 \mathrm{~h}$ after electroporation. In our previous experiments we have determined that $1400 \mathrm{~V} / \mathrm{cm}$ electric field strength yielded the most efficient electrotransfection of CHO-K1 cell line. Based on this, we used one, two, or three HV $(1400 \mathrm{~V} / \mathrm{cm}$ strength, $100 \mu$ s duration) pulses at $1 \mathrm{~Hz}$ frequency for cell electroporation. The percentage of GFP positive cells measured $24 \mathrm{~h}$ after electroporation is presented in Figure 1A, and the total fluorescence in these cells is shown in Figure 1B. We can see that both the number of transfected cells (transfection efficiency) and the total fluorescence of the cell population statistically significantly increased with the increasing plasmid concentration. After treatment with $1 \mathrm{HV}$ pulse, the number of transfected cells increases until $200 \mu \mathrm{g} / \mathrm{mL}$ concentration, the rise slows down in the $200-400 \mu \mathrm{g} / \mathrm{mL}$ range, but increases further after the plasmid concentration reaches $600 \mu \mathrm{g} / \mathrm{mL}$. After the application of two HV pulses, the number of transfected cells increases with the increasing plasmid concentration up to $300 \mu \mathrm{g} / \mathrm{mL}$, and then reaches the plateau, at least in the range of plasmid concentrations used. After the application of three HV pulses, the number of transfected cells increases up to $400 \mu \mathrm{g} / \mathrm{mL}$ plasmid concentration, where it reaches $82 \%$, which is the highest number of transfected cells achieved in all used conditions. However, the increase in plasmid concentration to $600 \mu \mathrm{g} / \mathrm{mL}$ when three $\mathrm{HV}$ pulses were used caused a statistically significant drop in transfection efficiency. The total fluorescence of the cells follows the same trend as the number of transfected cells, although no decrease in total cell fluorescence between $400-600 \mu \mathrm{g} / \mathrm{mL}$ plasmid concentrations after the treatment with three HV pulses is observed (see Figure 1B). It can also be seen that both the transfection efficiency and the total fluorescence of the cells is higher when a higher number of electric pulses is used.

The most interesting observation is the observed decrease in transfection efficiency after treatment with three HV pulses when the plasmid concentration changes from $400 \mu \mathrm{g} / \mathrm{mL}$ to $600 \mu \mathrm{g} / \mathrm{mL}$. This discrepancy has prompted us to evaluate the cell viability after electrotransfection. The results of these experiments are shown in Figure 2. With $1 \mathrm{HV}$ pulse, the cell viability statistically significantly decreases in comparison to the control $(0 \mu \mathrm{g} / \mathrm{mL}$ plasmid concentration $)$ at $200 \mu \mathrm{g} / \mathrm{mL}$ plasmid concentration, and no statistically significant differences were detected between cell viability after electrotransfection with plasmid concentrations higher than $200 \mu \mathrm{g} / \mathrm{mL}$. A similar trend is observed 
after electroporation with $2 \mathrm{HV}$ pulses. In these conditions, cell viability remains stable in the plasmid concentration range of $200-400 \mu \mathrm{g} / \mathrm{mL}$ but decreases further when a $600 \mu \mathrm{g} / \mathrm{mL}$ concentration is used. After the treatment with three HV pulses, the cell viability steadily decreases over the whole range of plasmid concentrations used, although statistical significance is not always observed between the closest neighboring points. Overall, cell viability decrease is higher after the application of three HV pulses than after the application of one or two HV pulses. The highest loss of cell viability is observed with three $\mathrm{HV}$ pulses and $600 \mu \mathrm{g} / \mathrm{mL}$ plasmid concentration, where it falls to $\sim 25 \%$.
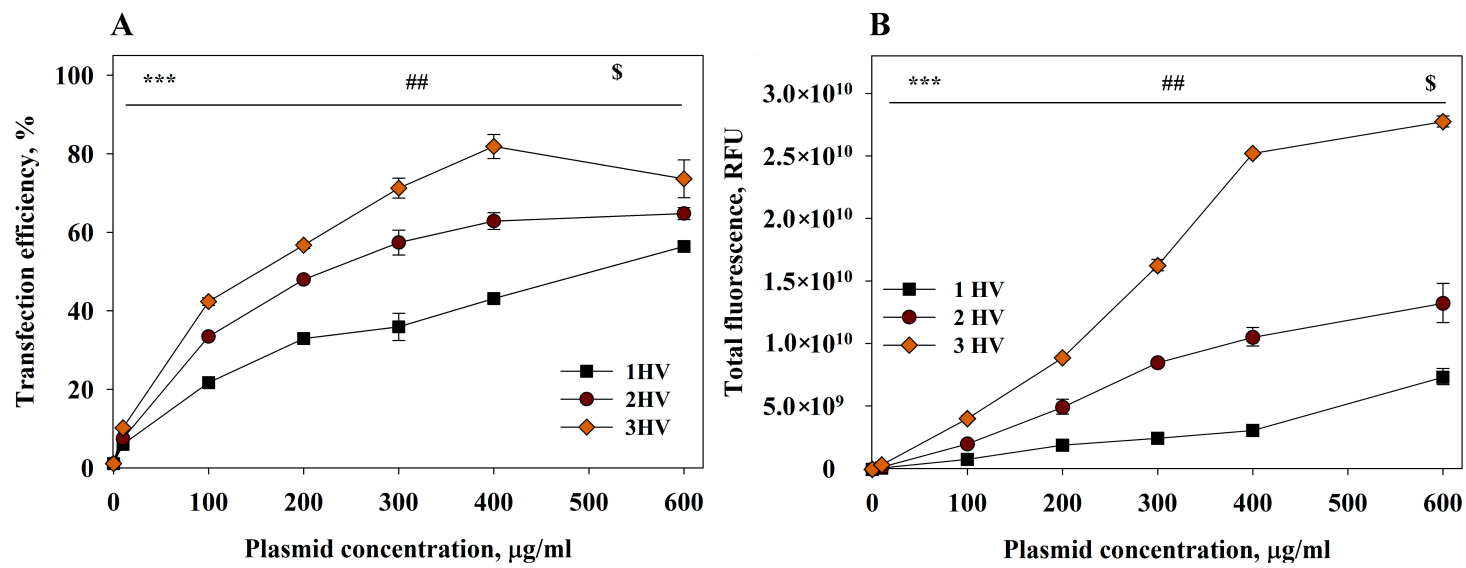

Figure 1. The dependence of cell electrotransfection efficiency (A) and total fluorescence (B) on the plasmid concentration after treatment with 1, 2 and $3 \mathrm{HV}(1400 \mathrm{~V} / \mathrm{cm}$ strength, $100 \mu$ s duration) pulses at $1 \mathrm{~Hz}$ repetition frequency. The results represent the transfected cells and do not account for cell viability changes. The concentration of GFP coding plasmid was 10-600 $\mu \mathrm{g} / \mathrm{mL}$. The point on each curve at $0 \mu \mathrm{g} / \mathrm{mL}$ plasmid concentration represents the control point (electroporation (EP) alone). Error bars represent standard error of mean (SEM). The significance of differences was calculated using one-way ANOVA. 3 symbols ${ }^{* * *}$ represents differences between neighboring points after treatment with $1 \mathrm{HV}$, \#\#-after treatment with $2 \mathrm{HV}$, and \$-after the treatment with $3 \mathrm{HV}$.

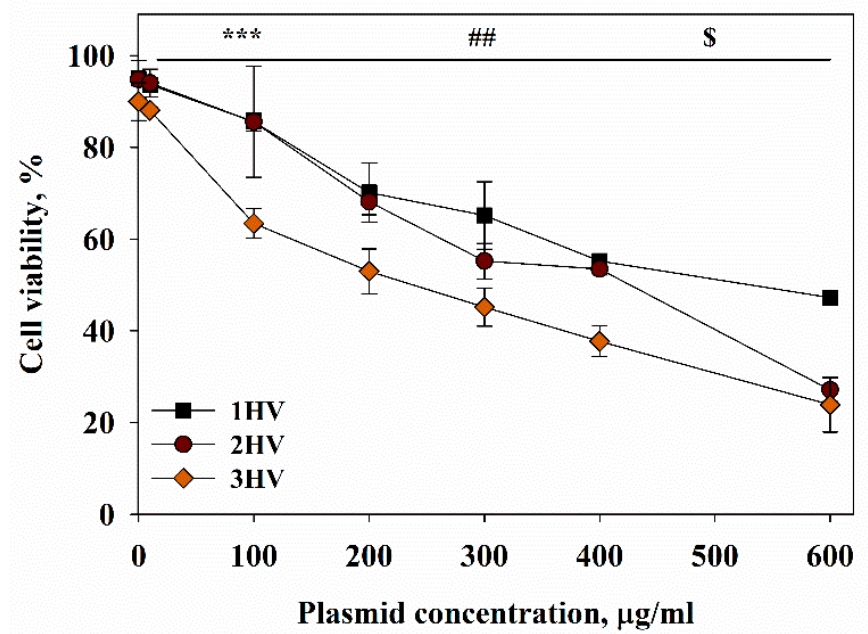

Figure 2. The dependence of cell viability on plasmid concentration after treatment with 1, 2 and $3 \mathrm{HV}$ $(1400 \mathrm{~V} / \mathrm{cm}, 100 \mu \mathrm{s})$ pulses at $1 \mathrm{~Hz}$ repetition frequency. The concentration of GFP coding plasmid was $10-600 \mu \mathrm{g} / \mathrm{mL}$. The point on each curve at $0 \mu \mathrm{g} / \mathrm{mL}$ plasmid concentration represents the control point (electroporation (EP) alone). Error bars represent standard error of mean (SEM). The significance of differences was calculated using one-way ANOVA. 3 symbols ${ }^{* * *}$ represents differences between neighboring points after treatment with $1 \mathrm{HV}$, \#\#-after treatment with $2 \mathrm{HV}$, and \$-after the treatment with $3 \mathrm{HV}$. 
As we observed a large change in cell viability in dependence of the plasmid concentration, we proceeded to analyze the number of transfected cells in the population of all treated cells (Figure 3A). Additionally, we observed the total fluorescence in these transfected cells (Figure 3B). We can see that the differences between the electric pulse conditions and the general shape of the curve's changes in comparison to the ones measured on the surviving cells alone (see Figure 1 for comparison). After treatment with $1 \mathrm{HV}$ pulse, the number of transfected cells increases with the increasing plasmid concentrations until $200 \mu \mathrm{g} / \mathrm{mL}$ plasmid concentration. After that, the number of transfected cells reaches a plateau and does not significantly increase with the higher plasmid concentrations used. After the treatment with either two or three HV pulses, the plateau in the number of transfected cells is reached at $100 \mu \mathrm{g} / \mathrm{mL}$ and stays unchanged with up to $400 \mu \mathrm{g} / \mathrm{mL}$ plasmid concentrations used. However, when the plasmid concentration is increased up to $600 \mu \mathrm{g} / \mathrm{mL}$, the number of transfected cells starts to statistically significantly decrease.
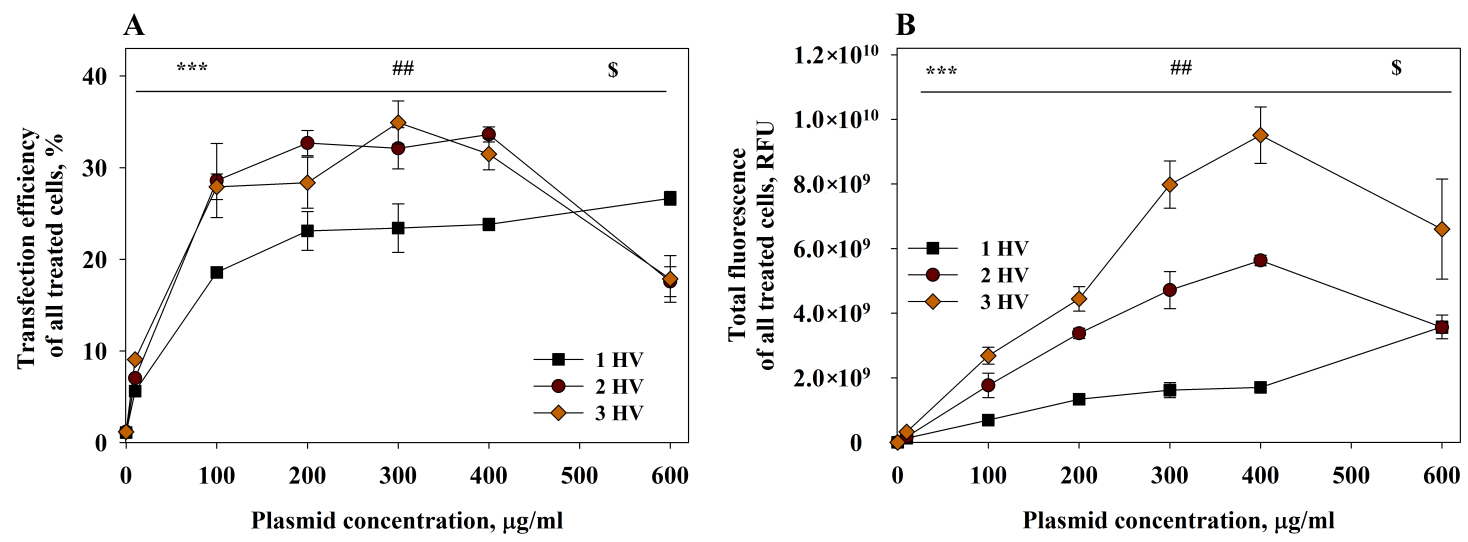

Figure 3. The dependence of treated cell electrotransfection efficiency (A) and total fluorescence (B) on plasmid concentration after treatment with 1,2 and $3 \mathrm{HV}(1400 \mathrm{~V} / \mathrm{cm}, 100 \mu \mathrm{s})$ pulses at $1 \mathrm{~Hz}$ repetition frequency. The results represent all treated cells and account for cell viability. The concentration of GFP coding plasmid was 10-600 $\mu \mathrm{g} / \mathrm{mL}$. Error bars represent standard error of mean (SEM). The significance of differences was calculated using one-way ANOVA. 3 symbols *** represents differences between neighboring points after treatment with $1 \mathrm{HV}$, \#\#-after treatment with $2 \mathrm{HV}$, and \$-after the treatment with $3 \mathrm{HV}$.

However, even though the number of transfected cells stays relatively similar over the plasmid concentration range of $200-400 \mu \mathrm{g} / \mathrm{mL}$, the total fluorescence of these cells does not. Irrespectively of the number of HV pulses used, the total fluorescence of the transfected cells increases up to $400 \mu \mathrm{g} / \mathrm{mL}$ plasmid concentration. With one HV, the total fluorescence increases further when the plasmid concentration is raised to $600 \mu \mathrm{g} / \mathrm{mL}$. However, with two and three HV pulses, the increase of plasmid concentration to $600 \mu \mathrm{g} / \mathrm{mL}$ causes the total fluorescence of the cell population to drop again, approaching similar level than the one seen with twice as low $300 \mu \mathrm{g} / \mathrm{mL}$ plasmid concentration.

\subsection{Transfection Efficiency and Cell Viability Dependence on the Distance between Electroporated Cell Membrane and the Nearest Plasmid}

The electrotransfection of the cells is dependent on the electrophoretic forces as the diffusion of plasmid sized DNA molecules is low even in aqueous solutions [29]. Therefore, on the same electric field parameters, the distance between the plasmid DNA and the plasma membrane, which is determined by the plasmid concentration, will determine how many DNA molecules will be able to reach the membrane. In turn, this will impact the transfection efficiency.

To address this, we have calculated the distance between the cell membrane and the nearest plasmid and plotted it against the plasmid concentration (Figure 4). We can see that the distance between the electroporated cell membrane and the nearest plasmid is directly dependent on plasmid 
concentration. However, the relation is non-linear and accurately $\left(R^{2}>0.95\right)$ satisfies the second order exponential fitting.

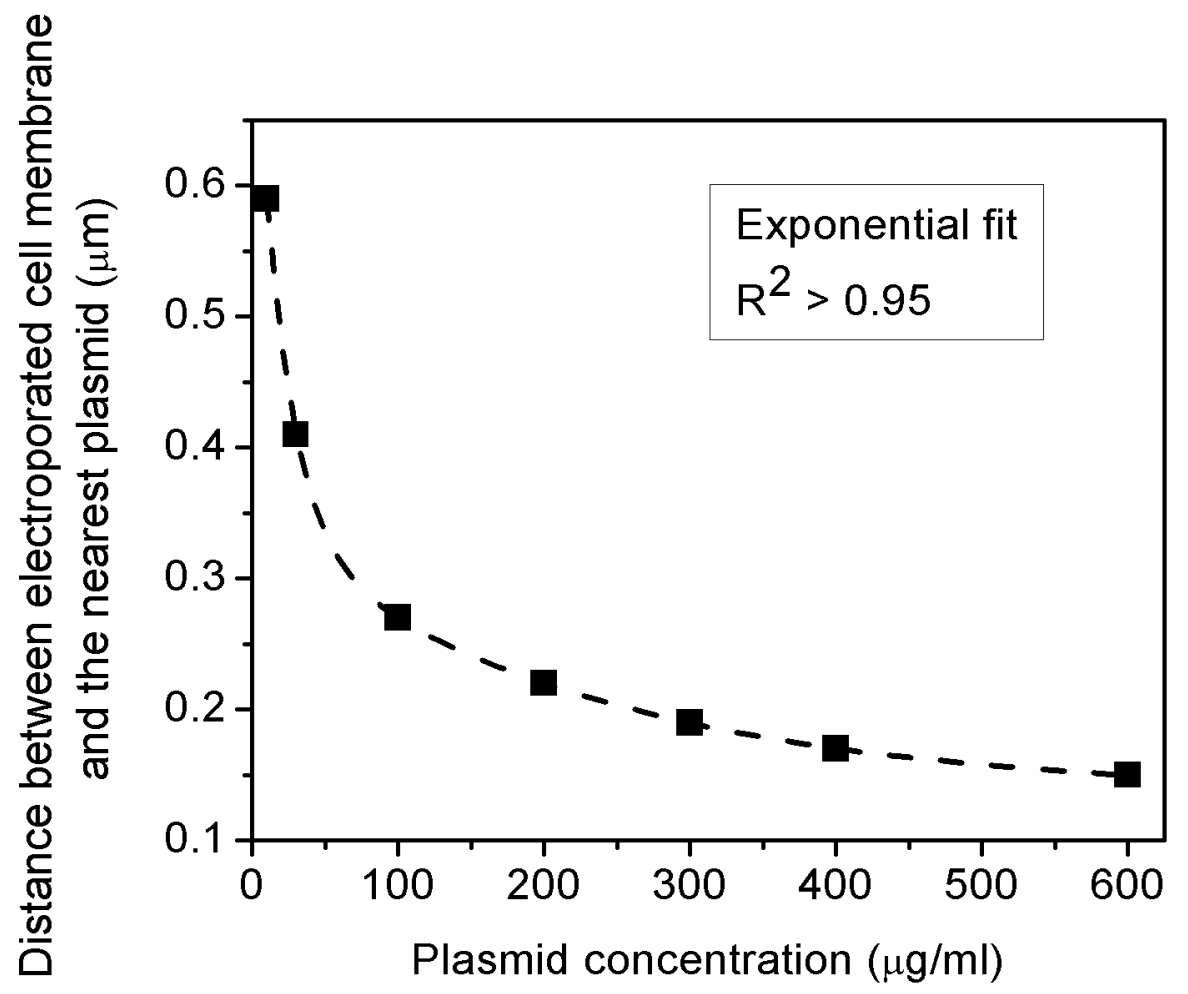

Figure 4. The dependence between the plasmid concentration and the distance between the electroporated cell membrane and the nearest plasmid.

If we plot the distance factor in the $\mathrm{x}$-axis and the number of transfected cells (Figure $5 \mathrm{~A}$ ) or cell viability (Figure $5 B$ ), we obtain the curves that adhere to a sigmoidal fit with good accuracy $\left(R^{2}>0.95\right)$.
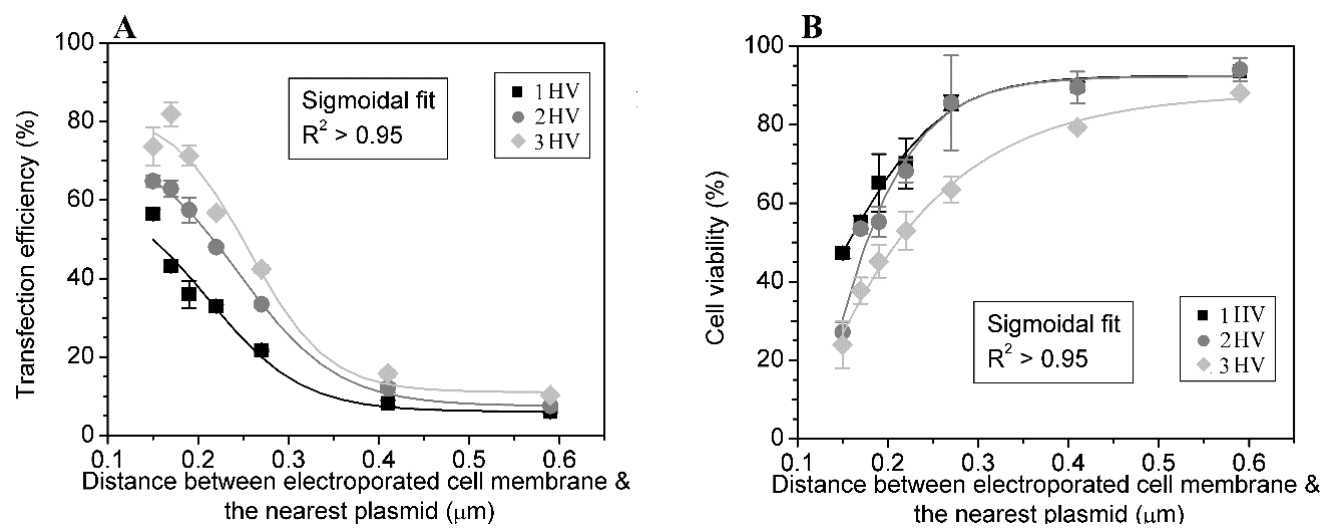

Figure 5. The dependence of the number of surviving cells with successful electrotransfection (A) and the cell viability (B) on the distance between electroporated cell membrane and the nearest plasmid.

The linear part of the sigmoidal curve in Figure 5A shows that transfection efficiency is highly dependent on the distance value in the range of $\sim 0.2-0.35 \mu \mathrm{m}$ as minor changes in the distance induce high changes in transfection efficiency. Therefore, small optimizations of other electroporation parameters while the plasmid concentration is in the aforementioned range will have the highest impact on the transfection efficiency. Conversely, when the distance value is higher $(>\sim 0.35 \mu \mathrm{m})$ or lower $(<\sim 0.2 \mu \mathrm{m})$ than the high sensitivity range, the transfection efficiency is not very sensitive to 
the changes in the distance between the plasmid and the membrane, with a small exception for $1 \mathrm{HV}$ electroporation conditions and low distance between the cell and the plasmid. The stabilization of transfection efficiency at distances lower than $0.2 \mu \mathrm{m}$ after the treatment with two or three HV pulses is due to the increasing cell death in these conditions. Indeed, the cell viability curves for all the pulse combinations are stationary for distances higher than $\sim 0.3 \mu \mathrm{m}$ and then start to decrease linearly with decreasing distance between the membrane and the plasmid (see Figure 5B).

\section{Discussion}

The previous research on electroporation optimization focused mostly on the empirical determination of input parameters that describe electric field or single characteristics of the medium [31]. However, the relationship between the input parameters and the therapeutic outcome is indirect, as the final state of the system is achieved over time due to the redistribution of the constituents induced by biophysical processes. For this reason, the response of the system to the external trigger (e.g., electric field) leads to different outcomes (e.g., electroporation efficiency). However, output parameters describe the system dynamics more precisely, making them more suitable to estimate the efficiency [32]. In our case, the output parameter is the distance between the electroporated membrane and the plasmid, which incorporates not only plasmid DNA concentration, but also the cell size and concentration. As such, it allows for more precise characterization of the system than the input parameter (plasmid DNA concentration). This helps to determine optimal conditions for electroporation as the output parameter directly exhibits the dynamics of the system. Therefore, plotting the distance value, which is non-linearly related to the plasmid concentration, versus transfection efficiency (see Figure 5A) reveals new results that are masked in the original representation of the results (see Figure 1A). Namely, there is a sigmoidal dependency between the distance value and the number of transfected cells, and the latter is most sensitive to the distance value in the $0.22-0.4 \mu \mathrm{m}$ region. When the distance is higher or lower, this sensitivity is lost, causing the lag and stationary parts of the graph. Plotting the distance against cell viability (See Figure 5B) reveals stationary part when the distance value is above $\sim 0.3 \mu \mathrm{m}$, and the cell viability starts decreasing at lower distances irrespectively of the pulse number. This implies that $\sim 0.3 \mu \mathrm{m}$ is a threshold below which the DNA induces negative effect on cell viability. Additionally, the sigmoidal part of the curve illustrates a clear three stage biophysical process with lag, linear, and saturation phases.

The presence of the transition state/point of the curves (Figure 5A,B) allow to clearly differentiate between the therapeutic strategies, depending on the particular necessities of the therapy: i) choose DNA concentration in the range corresponding to the distances $>\sim 0.2 \mu \mathrm{m}$ and achieve the cell transfection efficiency while preserving high cell viability (in overall $>\sim 45 \%$ ) or ii) increase plasmid DNA concentration (corresponding distance $<\sim 0.2 \mu \mathrm{m}$ ) to induce high cell death (in overall $<\sim 45 \%$ ) for maximal anticancer effect by killing the cancerous cells.

The increase in transfection efficiency when the distance is lowered can be explained by the increased efficiency of electrophoresis. It is well known that the interaction of plasmid DNA and electroporated membrane to form DNA/membrane complex is essential for successful electrotransfection $[9,15,33]$.

The electrophoretic force depends on the strength, number, and duration of the applied electric field. In turn, the magnitude of the electrophoretic force is one of the factors that determine the electrophoretic motility of the charged molecules [34,35]. A highly charged molecule, such as a plasmid, will move a certain distance once affected with a specific electric pulse [28]. However, with increase of plasmid concentration, the distance between the plasmids decreases (see Figure 4), and therefore lower electric field parameters might be required to achieve the same amount of plasmids reaching the cell due to electrophoresis.

The application of more electric pulses for electrotransfection increases the lifetime of the electropores as well as the electrophoretic force induced by the electric field. Therefore, the distance plasmid DNA can migrate from to form the DNA/membrane complex is larger. This allows us to 
achieve a higher number of transfected surviving cells at lower plasmid DNA concentrations (see Figure 1A). It is interesting to note that equivalent electrotransfection efficiency can be gained either by increasing the number of pulses and, accordingly, the electrophoretic force, or increasing the plasmid concentration and consequently decreasing the distance between electroporated cell and the nearest plasmid. This indicates that an increase in plasmid concentration can compensate the lower number of electric pulses and vice versa.

Here, we also show the cell viability decrease when a high concentration of plasmid DNA is in the extracellular medium while electric fields are applied. It is known that during the application of an appropriate electric field on cell suspension containing plasmid DNA, DNA/membrane complexes form as a result of electroporation process. After the formation of DNA/membrane complex, the plasmid DNA enters the cytoplasm via endocytotic processes [15,36-38]. Different types of endocytosis have been implicated in the plasmid internalization, including macropinocytosis, clathrin mediated and caveolin/raft mediated endocytosis [39]. Therefore, plasmid DNA can be found in various endosomes: early, late, recycling endosomes, and lysosomes. Some of these plasmids successfully enter nucleus and expression of encoded foreign gene starts.

However, endocytosis mediated plasmid DNA entrance can also trigger cell defense mechanisms against bacterial or viral infections, leading to programmed cell death [40-42]. This, in turn, may lead away from the desired process of electrotransfection to the programmed cell death [43]. Our results indicate that higher concentration of plasmid DNA in cell suspension leads to a significantly higher expression of foreign gene, hence it can be assumed that higher amount of plasmid DNA has entered into the cell. Having that in mind, the cell defense mechanisms are also more likely to be triggered, since higher amount of naked DNA is present in the cell cytosol. This interpretation allows the explanation of both higher cell death and higher transfection efficiency when a large number of plasmids are present in the extracellular medium. Based on our experimental data, two HV pulses with $200 \mu \mathrm{g} / \mathrm{mL}$ plasmid concentration are optimal conditions in order to achieve good transfection efficiency while maintaining the cell viability.

\section{Conclusions}

In summary, we show the inverse dependence of electrotransfection efficiency and cell viability. We also show that electrotransfection efficiency can be achieved by increasing the number of electric pulses, and therefore the electrophoretic force, or by increasing plasmid concentration and consequently decreasing the distance between the electroporated cell and the nearest plasmid. Additionally, we show that high plasmid DNA concentration induces a decrease in cell viability. We also propose the distance between the electroporated membrane and nearest plasmid as a more accurate measure predicting the electrotransfection efficiency.

Author Contributions: S.C., P.R., and S.Š. conceived and designed the experiments; S.C. and P.R. performed the experiments; S.C., P.R., M.M., and M.J. analyzed the data; S.C. wrote the paper; S.Š. and M.J. reviewed and edited the paper. All authors have read and agreed to the published version of the manuscript.

Funding: This research is funded by the European Social Fund according to the activity 'Improvement of researchers' qualification by implementing world-class R\&D projects' of Measure No. 09.3.3-LMT-K-712-01-0188.

Conflicts of Interest: The authors declare no conflict of interest.

\section{References}

1. Lundstrom, K. Viral Vectors in Gene Therapy. Diseases 2018, 6, 42. [CrossRef] [PubMed]

2. Lambkin-Williams, R.; Noulin, N.; Mann, A.; Catchpole, A.; Gilbert, A.S. The human viral challenge model: Accelerating the evaluation of respiratory antivirals, vaccines and novel diagnostics. Respir. Res. 2018, 19, 123. [CrossRef] [PubMed] 
3. Yildirim, C.; Nieuwenhuis, S.; Teunissen, P.F.; Horrevoets, A.J.; van Royen, N.; van der Pouw Kraan, T.C. Interferon-Beta, a Decisive Factor in Angiogenesis and Arteriogenesis. J. Interferon Cytokine Res. 2015, 35, 411-420. [CrossRef]

4. Neumann, E.; Rosenheck, K. Permeability changes induced by electric impulses in vesicular membranes. J. Membr. Biol. 1972, 10, 279-290. [CrossRef]

5. Bernhardt, J.; Pauly, H. On the generation of potential differences across the membranes of ellipsoidal cells in an alternating electrical field. Biophysik 1973, 10, 89-98. [CrossRef] [PubMed]

6. Valic, B.; Golzio, M.; Pavlin, M.; Schatz, A.; Faurie, C.; Gabriel, B.; Teissie, J.; Rols, M.P.; Miklavcic, D. Effect of electric field induced transmembrane potential on spheroidal cells: Theory and experiment. Eur. Biophys. J. 2003, 32, 519-528. [CrossRef]

7. Gabriel, B.; Teissi Â, J. Direct observation in the millisecond time range of fluorescent molecule asymmetrical interaction with the electropermeabilized cell membrane. Biophys. J. 1997, 73, 2630-2637. [CrossRef]

8. Hibino, M.; Shigemori, M.; Itoh, H.; Nagayama, K.; Kinosita, K., Jr. Membrane conductance of an electroporated cell analyzed by submicrosecond imaging of transmembrane potential. Biophys. J. 1991, 59, 209-220. [CrossRef]

9. Satkauskas, S.; Ruzgys, P.; Venslauskas, M.S. Towards the mechanisms for efficient gene transfer into cells and tissues by means of cell electroporation. Expert Opin. Biol. Ther. 2012, 12, 275-286. [CrossRef]

10. Gehl, J. Electroporation: Theory and methods, perspectives for drug delivery, gene therapy and research. Acta Physiol. Scand. 2003, 177, 437-447. [CrossRef]

11. Rajeckaite, V.; Jakstys, B.; Rafanavicius, A.; Maciulevicius, M.; Jakutaviciute, M.; Satkauskas, S. Calcein Release from Cells In Vitro via Reversible and Irreversible Electroporation. J. Membr. Biol. 2018, 251, 119-130. [CrossRef] [PubMed]

12. Weaver, J.C. Electroporation theory. Concepts and mechanisms. Methods Mol. Biol. 1995, 55, 3-28. [PubMed]

13. Son, R.S.; Smith, K.C.; Gowrishankar, T.R.; Vernier, P.T.; Weaver, J.C. Basic features of a cell electroporation model: Illustrative behavior for two very different pulses. J. Membr. Biol. 2014, 247, 1209-1228. [CrossRef] [PubMed]

14. Chabot, S.; Pelofy, S.; Teissie, J.; Golzio, M. Delivery of RNAi-Based Oligonucleotides by Electropermeabilization. Pharma. Basel 2013, 6, 510-521. [CrossRef]

15. Escoffre, J.M.; Portet, T.; Favard, C.; Teissie, J.; Dean, D.S.; Rols, M.P. Electromediated formation of DNA complexes with cell membranes and its consequences for gene delivery. Biochim. Biophys. Acta 2011, 1808, 1538-1543. [CrossRef]

16. Rosazza, C.; Phez, E.; Escoffre, J.M.; Cezanne, L.; Zumbusch, A.; Rols, M.P. Cholesterol implications in plasmid DNA electrotransfer: Evidence for the involvement of endocytotic pathways. Int. J. Pharm. 2012, 423, 134-143. [CrossRef]

17. Rosazza, C.; Buntz, A.; Riess, T.; Woll, D.; Zumbusch, A.; Rols, M.P. Intracellular tracking of single-plasmid DNA particles after delivery by electroporation. Mol. Ther. 2013, 21, 2217-2226. [CrossRef]

18. Neumann, E.; Schaefer-Ridder, M.; Wang, Y.; Hofschneider, P.H. Gene transfer into mouse lyoma cells by electroporation in high electric fields. EMBO J. 1982, 1, 841-845. [CrossRef]

19. Cepurniene, K.; Ruzgys, P.; Treinys, R.; Satkauskiene, I.; Satkauskas, S. Influence of plasmid concentration on DNA electrotransfer in vitro using high-voltage and low-voltage pulses. J. Membr. Biol. 2010, 236, 81-85. [CrossRef]

20. Niakan, S.; Heidari, B.; Akbari, G.; Nikousefat, Z. Comparison of Different Electroporation Parameters on Transfection Efficiency of Sheep Testicular Cells. Cell J. 2016, 18, 425-437.

21. Haberl, S.; Kanduser, M.; Flisar, K.; Hodzic, D.; Bregar, V.B.; Miklavcic, D.; Escoffre, J.M.; Rols, M.P.; Pavlin, M. Effect of different parameters used for in vitro gene electrotransfer on gene expression efficiency, cell viability and visualization of plasmid DNA at the membrane level. J. Gene Med. 2013, 15, 169-181. [CrossRef]

22. Kanduser, M.; Sentjurc, M.; Miklavcic, D. Cell membrane fluidity related to electroporation and resealing. Eur. Biophys. J. 2006, 35, 196-204. [CrossRef]

23. Muller, W.E.; Zahn, R.K. Determination of the bleomycin-inactivating enzyme in biopsies. GANN Jpn. J. Cancer Res. 1976, 67, 425-430.

24. Pavlin, M.; Miklavcic, D. Theoretical and experimental analysis of conductivity, ion diffusion and molecular transport during cell electroporation-Relation between short-lived and long-lived pores. Bioelectrochemistry 2008, 74, 38-46. [CrossRef] 
25. Pucihar, G.; Kotnik, T.; Kandušer, M.; Miklavčič, D. The influence of medium conductivity on electropermeabilization and survival of cells in vitro. Bioelectrochemistry 2001, 54, 107-115. [CrossRef]

26. Helledie, T.; Nurcombe, V.; Cool, S.M. A simple and reliable electroporation method for human bone marrow mesenchymal stem cells. Stem. Cells Dev. 2008, 17, 837-848. [CrossRef] [PubMed]

27. Liew, A.; Andre, F.M.; Lesueur, L.L.; De Menorval, M.A.; O’Brien, T.; Mir, L.M. Robust, efficient, and practical electrogene transfer method for human mesenchymal stem cells using square electric pulses. Hum. Gene Ther. Methods 2013, 24, 289-297. [CrossRef] [PubMed]

28. Pavlin, M.; Kanduser, M. New insights into the mechanisms of gene electrotransfer-Experimental and theoretical analysis. Sci. Rep. 2015, 5, 9132. [CrossRef] [PubMed]

29. Lesueur, L.L.; Mir, L.M.; Andre, F.M. Overcoming the Specific Toxicity of Large Plasmids Electrotransfer in Primary Cells In Vitro. Mol. Ther. Nucleic Acids 2016, 5, e291. [CrossRef]

30. Lukacs, G.L.; Haggie, P.; Seksek, O.; Lechardeur, D.; Freedman, N.; Verkman, A.S. Size-dependent DNA mobility in cytoplasm and nucleus. J. Biol. Chem. 2000, 275, 1625-1629. [CrossRef]

31. Sungailaite, S.; Ruzgys, P.; Satkauskiene, I.; Cepurniene, K.; Satkauskas, S. The dependence of efficiency of transmembrane molecular transfer using electroporation on medium viscosity. J. Gene Med. 2015, 17, 80-86. [CrossRef] [PubMed]

32. Hallow, D.M.; Mahajan, A.D.; McCutchen, T.E.; Prausnitz, M.R. Measurement and correlation of acoustic cavitation with cellular bioeffects. Ultrasound Med. Biol. 2006, 32, 1111-1122. [CrossRef]

33. Sukharev, S.I.; Klenchin, V.A.; Serov, S.M.; Chernomordik, L.V.; YuA, C. Electroporation and electrophoretic DNA transfer into cells. The effect of DNA interaction with electropores. Biophys. J. 1992, 63, 1320-1327. [CrossRef]

34. Zholkovskij, E.K.; Masliyah, J.H.; Shilov, V.N.; Bhattacharjee, S. Electrokinetic Phenomena in concentrated disperse systems: General problem formulation and Spherical Cell Approach. Adv. Colloid Interface Sci. 2007, 134-135, 279-321. [CrossRef]

35. Oshima, H. Electrokinetic phenomena in a suspension of liquid drops. Interface Sci. Technol. 2006, 12, 182-202. [CrossRef]

36. Golzio, M.; Teissié, J.; Rols, M. Cell synchronization effect on mammalian cell permeabilization and gene delivery by electric field. Biochim. Biophys. Acta BBA Biomembr. 2002, 1563, 23-28. [CrossRef]

37. Faurie, C.; Rebersek, M.; Golzio, M.; Kanduser, M.; Escoffre, J.M.; Pavlin, M.; Teissie, J.; Miklavcic, D.; Rols, M.P. Electro-mediated gene transfer and expression are controlled by the life-time of DNA/membrane complex formation. J. Gene Med. 2010, 12, 117-125. [CrossRef]

38. Paganin-Gioanni, A.; Bellard, E.; Escoffre, J.M.; Rols, M.P.; Teissie, J.; Golzio, M. Direct visualization at the single-cell level of siRNA electrotransfer into cancer cells. Proc. Natl. Acad. Sci. USA 2011, 108, 10443-10447. [CrossRef]

39. Rosazza, C.; Meglic, S.H.; Zumbusch, A.; Rols, M.P.; Miklavcic, D. Gene Electrotransfer: A Mechanistic Perspective. Curr. Gene Ther. 2016, 16, 98-129. [CrossRef]

40. Cheng, G.; Zhong, J.; Chung, J.; Chisari, F.V. Double-stranded DNA and double-stranded RNA induce a common antiviral signaling pathway in human cells. Proc. Natl. Acad. Sci. USA 2007, 104, 9035-9040. [CrossRef]

41. Jones, J.W.; Kayagaki, N.; Broz, P.; Henry, T.; Newton, K.; O’Rourke, K.; Chan, S.; Dong, J.; Qu, Y.; Roose-Girma, M.; et al. Absent in melanoma 2 is required for innate immune recognition of Francisella tularensis. Proc. Natl. Acad. Sci. USA 2010, 107, 9771-9776. [CrossRef] [PubMed]

42. Ishii, K.J.; Kawagoe, T.; Koyama, S.; Matsui, K.; Kumar, H.; Kawai, T.; Uematsu, S.; Takeuchi, O.; Takeshita, F.; Coban, C.; et al. TANK-binding kinase-1 delineates innate and adaptive immune responses to DNA vaccines. Nature 2008, 451, 725-729. [CrossRef] [PubMed]

43. Li, L.H.; Sen, A.; Murphy, S.P.; Jahreis, G.P.; Fuji, H.; Hui, S.W. Apoptosis Induced by DNA Uptake Limits Transfection Efficiency. Exp. Cell Res. 1999, 253, 541-550. [CrossRef] [PubMed]

(C) 2020 by the authors. Licensee MDPI, Basel, Switzerland. This article is an open access article distributed under the terms and conditions of the Creative Commons Attribution (CC BY) license (http://creativecommons.org/licenses/by/4.0/). 